\title{
Development of the Sundanese Pantun Performance in Mang Ayi Style
}

\author{
Bagja Pitriyana*, Yudi Sukmayadi \\ Universitas Pendidikan Indonesia \\ Bandung, Indonesia \\ *Bagdja15@upi.edu
}

\begin{abstract}
Sundanese pantun is a type of art performed by a juru pantun. The Sundanese pantun tells of a play in the form of a story sung to the accompaniment of a lute. Usually the Sundanese Pantun art is usually performed in ngaruwat (ritual) events with due observance of the prevailing standards. However, the singer of the pantun Mang Ayi transforms the Sundanese Pantun into a new "package" in each of his performances. The purpose of this study was to determine the extent of the development process of the Sundanese Pantun performance, especially the Mang Ayi style. This study used a quantitative descriptive research method with the umbrella of ethnomusicology theory. The results showed that the development of Mang Ayi's Sundanese Pantun show had changes in the structure of the show, including the addition of waditra Gembyung, kendang, kecrek, goong. and a repertoire of popular Sundanese songs, namely Ya lamaleui, Engko, siuh and so on.
\end{abstract}

Keywords-Sundanese pantun, development, waditra

\section{INTRODUCTION}

Along with the times, it certainly has an influence on innovation in art. Inovasion is away that is done as a solution [1]. The same is the case with developments in the structure of the Sundanese pantun performance in the mang ayi style, which has its own characteristics in each performance but still adheres to the norms of traditional culture. Mang The promotion of culture was born in the framework of protecting, utilizing and developing Indonesia culture [2]. Based on the innovation and popularity mang Ayi in performing Sundanese pantun, it can be proven by his activeness in filling in various events so that he has received many award from the government or traditional institutions and community leaders.

The existence of the Sundanese pantun performance in the style of mang Ayi, can be accepted by various levels of society, both formal and non-formal, at the national and international levels. The interaction between the audience and the singer of the pantun, such as performing activities of dancing while doing a nyawer (giving money to the singer) is unique in the Sundanese rhyme performance which is packaged by Mang Ayi.

There are mandatory rules that must be carried out by the pantun singer, starting from the pre-show until the time of the performance. The performance of the Sundanese pantun is a rite, there are too many requirements that must be done before, during and after the performance [3]. In every performance the poet must master the story, by singing it while playing kacapi. This role is an important part of the show. Apart from these points, the development of the mang ayi style Sundanese rhyme performance with the addition of waditra, performance structures, and the presence of song reports that are popular in the community in their presentation cannot be separated from noble norms which of course have a relationship with values in character education such as religion, tolerance, and love the homeland.

This is one of the efforts made by Mang Ayi as juru pantun in innovating Sundanese pantun art so that it is still accepted in today's modern society, by utilizing art as a place to create and innovate while still adhering to traditional norms that can provide education.

Previous research on Sundanese rhymes entitled "The music of rhymes, an epic narrative tradition of West Java, Indonesia" by Weintrab A.N. in the University of Hawaii thesis. reveals the formal structure and melody of songs in $\mathrm{Ki}$ Enjun's repertoire.

Next, there is research from Ela Yulaeliah about "Sundanese Pantun Art as a means of ritual and entertainment" thesis. ISI Yogyakarta. qualitative research with an approach multidisciplinary. Observing pantun as an art and its function among the native Sundanese-speaking communities in West Java.

The previous research above, it can be ascertained that the research focal point is different. This study aims to discuss how the development of the Sundanese pantun in mang Ayi style, which will be studied based on the text and its context with a focus on the structure of the show, and waditra.

\section{LITERATURE REVIEW}

The swift flow of the times has greatly influenced human life. Changes in style and competition make people continue to think and innovate so that life's needs are met. And challenges in modern life, one of which is that every individual is competing to be more recognized for their existence, thus 
affecting the way of communicating in the order of everyday life

Changing the habits of an agrarian society into an industry and being completely digital has become a challenge for traditional art activists, one of which is Mang Ayi, a Sundanese pantun artist from Subang who is known as a pantunist. because the Sundanese pantun art is an art that is identical with the many requirements in its performance. The performance of Sundanese pantun is a rite, there are too many requirements that must be done before, during, and after the performance [3]. These requirements are the basis for mang Ayi in every performance, but seeing the changing times, Mang Ayi tries to adapt the packaging of Sundanese pantun performances according to the needs of the sosiety, with the aim that Sundanese pantun art is still recognized by the public.with the birth of the creative pantun, it is the development of an expanded form the buhun pantun wich turn out to be accepted to the community even though it does not eliminate its original form [4].

Studying Sundanese pantun performances cannot be separated from the text and context. This study aims to analyze the performance structure of the Sundanese pantun mang Ayi style, waditra analysis because the role of waditra in the accompaniment of the sundanese pantun performances is an important part that cannot be separated. Waditra is the result of the ability of the sundaneses people to the develop their culture system [5]. The study, the researcher focused on the study using the ethnomusicology discipline. Ethnomusicology exist in its own seed and division, for that it is always combined in different parts, musicological and ethnological and perhaps the discussion $I$ the mixing of the two in a unique way not emphasizing but considering the two [6]. With the assessment in the research, it is hoped that it can be useful for artists, academics and the wider community.

\section{METHODS}

In this study, the qualitative paradigm with the descriptive analysis method was used by the researcher as a key instrument of the data found. Qualitative research intends to understand what is understood by research subjects by means of descriptions in a special natural context [7]. To complement the researcher data, it was accompanied by observation, documentation and interviews as data collection techniques. The research location was conducted in Sadawarna village, Cibogo sub-district, Subang district. with the source of the pantun interpreter mang Ayi.

\section{RESUlT AND DISCUSIION}

Based on research and observations of mang Ayi's Sundanese pantun, researchers found that the origin of the presentation of mang Ayi's Sundanese pantun used the format of a kacapi player - Mang Ayi, alok and a ngukus singer. By using the structure of the bubuka show, the contents and the end. In the content or essence of Mang Ayi, it only focuses on telling a play accompanied by kacapi. And only performed in rituals, ruwatan for the sake of the earth.

\section{A. Ritual Sundanese Pantun Mang Ayi}

In the performance of the Sundanese pantun, the mang Ayi ritual, there are several special stories that must be in accordance with the ritual ceremony, including:

- Ruwat Bumi, cerita yang dibawakan: Raden Pamanah rasa.

- Turun Nyambut, narrated by: Bah Mangkubumi

- Ruwat Bumi Enggal, narrated by: Ciung Wanara.

Showtime:

Held at night at 20.30-11.30 (ngarajah jeung nyarita), followed by a ngaruwat event which was held starting at 11.30 - 12.00. implementation of the show, all carried out in the open space (home page) of the person performing.

With the increasing number of calls to perform rhymes, Mang Ayi was motivated to develop the Sundanese pantun art from ritual to entertainment.

1) Performance of Sundanese Pantun in mang Ayi style: The performances are not much different from ritual events. The story that is told is not special like the story in a ritual ceremony, it usually depends on the invitee. The poet can tell the story of Lutung Kasarung, Ki Lapidin, Nyi Mas Subanglarang, Raden Pamanahrasa. Ciung Wanara, Mundinglaya and Bah Mangkubumi. What distinguishes it is that the pantunist always supervises the story with buhun gembyung songs such as cranks, Rincik Manik, Malong, Kentrung, Ayun Ambing, Yolaillah and siuh.

The changes to the Sundanese mang Ayi pantun are part of the development in his performance offerings. The development of the Sundanese pantun Mang Ayi was developed with the aim of maintaining the existence of Sundanese rhyme performances in order to be accepted by the community.

a) Special rituals: In its packaging, mang Ayi's Sundanese pantun has changed from ritual art to entertainment art. however, the performance of Sundanese pantun mang Ayi does not leave any special rituals before the Sundanese pantun performance begins. It's not just that Mang Ayi as the pantunist, Juru Kukus and Juru Ruwat, also performs a special fasting ritual, and is not allowed to eat until the rhyme performance is over. This is done so that during the process of solemn performances.

b) Sundanese pantun equipment: Sasajen in Sundanese rhyme performance mang Ayi is an element of performance that must be available because it is a condition, if there is no sasajen, Sundanese pantun performances cannot be carried out. As for the meaning of the sasajen of the Sundanese pantun performance according to the interpreter of the alok 
Dedi Rusdi: "so that the people around the Sundanese pantun performance are sarasa jeung sa ajen". As symbols that the audience must read. The types of sasajen include fruits, beureum porridge, bodas porridge, perfumed oil, whiting, cigarettes, symbols or kias, bakakak, black coffee, tea water, a free-range chicken egg, and coconut.

2) The development structure of the Sundanese Pantun show mang Ayi: The performance structure of mang Ayi's Sundanese pantun is divided into three parts, namely the Beginning (Opening). The second part (Content / core). And Part Three (End).

a) Part early opening (Bubuka): The early part of mang Ayi's Sundanese pantun performance begins with ngukus. Ngukus is the activity of burning incense by saying prayers carried out by the steamer, which is used for safety in performances and blessings for people who invite Sundanese pantun art. In his prayer, a special prayer was included for the karuhun, the companions of the Prophet. and prayers for the prophets. Starting from Prophet Muhammad SAW to Prophet Adam AS

b) Contents (Core): The core part of the Sundanese pantun mang Ayi begins with the song benjang. This benjang song functions as a bridge to the rajah, the chanted rajah is arranged into three parts, namely rajah bubuka, rajah Buah Sadulur, and rajah kanjeng Rosululloh.

The content of the Sundanese pantun performance, mang Ayi, tells a lot about the life of the Sundanese people, the story of Prabu Siliwangi, the kingdom of Padjajaran, Dewi Sri, Nay Subang Larang as well as sacred stories such as Lutung Kasarang, Mundinglaya. However, in the structure of this performance the researcher found differences. This difference arises when mang Ayi enters the content structure (core), when conveying the essence of the rhyme story, mang Ayi packs it by giving a pause, then presents traditional Sundanese songs that are liked by the audience accompanied by musical figures other than kacapi. The presentation of the songs here has a function as an interaction between the presenter and the audience, the interaction here is like the audience dancing, giving saweran, sometimes singing along. The interaction process is part of the development of the structure of the Sundanese mang Ayi pantun in every performance.

c) Part three: After telling the story or the end of the show, mang Ayi is closed with a rajah pamunah, followed by a ruwat interpreter reading a special incantation that cannot be heard without the accompaniment of kacapi. After that the Sundanese pantun performance was finished.

3) Waditra: In the performance of the Sundanese pantun mang Ayi, waditra kacapi is the main waditra played by the rhetorician. The kacapi passages are very supportive in delivering Rajah and the essence of the story. So that it can invite the imagination of the listeners.
The sound of the waditra kacapi, apart from being an accompaniment, is the kacapi which acts as an introduction to the pantunist's intrigue in storytelling. In the accompaniment, it also has a distinctive shape in its parts. The accompaniment of kacapi composer of mang Ayi's pantun is a rajah accompaniment pattern, a satirical accompaniment pattern and a variation pattern during the pantun dialogue. make a color pattern on the parts. Apart from kacapi, the waditra used in the development of the Ayi Sundanese pantun is a set of gembyung, drums, goong and kecrek. With the addition of waditra in the performance of the Sundanese mang Ayi pantun, of course there are additional players and also sinden in the show. And all the existing waditra have a function as an accompaniment to the song. As for the title song which is usually played to accompany the song detail, Manik Manik, Benjang, Ya bissmillah, Engko is also a mess. not infrequently mang Ayi performed songs by combining several songs (medley). This process is one of the concepts of the development of the mang Ayi Sundanese pantun performance.

\section{4) The values of Sundanese pantun performances}

a) Sesajen: Sesajen in the mang Ayi show contain various kinds of fruits that taste sweet, sour and pait as well as various kinds of fruit colors. Offerings are a mandatory part, in that their performances are closely related to noble values. that the sesajen is a symbol for humans to be grateful for the results of natural arrangements and also related to the context of the surrounding community, the majority of which are still natural products as necessities.

b) Sundanese pantun performance content: The content of the Sundanese pantun performance, filled with the opening in the opening, contains a rajah when interpreted in Indonesian, namely a prayer addressed to God Almighty. Prayer is proof that humans have no power and effort except with the permission of Allah SWT. This means that in Sundanese pantun performances there is an application of the spiritual values of Religion.

\section{CONCLUSION}

Based on the research, it can be concluded that in general, the Sundanese mang Ayi pantun performance has the text and context that is applied, related to the structure of the performance, performance equipment and waditra. the development of Sundanese pantun performances in mang Ayi's style reflects the changing habits of the surrounding community. Then divide into two concepts. The concept of ritual performances and the concept of entertainment Sundanese pantun performances. The results obtained are an effort to innovate so that the Sundanese pantun art is still present in the midst of society and even extends to various levels of society. 


\section{REFERENCES}

[1] N. Rokhim, "Inovasi kesenian rakyat kuda lumping di Desa Gandu, Kecamatan tembarak kabupaten temanggung," Greget: Jurnal Pengetahuan dan Penciptaan Tari, vol. 17, no. 1, 2018.

[2] UUD RI Nomor 5. Tahun 2017. Pemajuan Kebudayaan.

[3] J. Sumardjo, Seni Pertunjukan Indonesia. Bandung: STSI Press, 2001.
[4] E. Yulaesiah, Kehidupan dan perkembangn pntun Sunda di Ujung berung Jawa barat. Yogyakarta: Tesis ISI, 1990.

[5] Koentjaraningrat, Pengantar Ilmu Antropologi. Jakarta: Rineka Cipta, 2009.

[6] A.P. Merriam, The Antropology of Music. Indiana: North University, 1964.

[7] L.J. Moleong, Metodologi Penelitian Kualintatif. Bandung: Remaja Rosdakarya, 2010. 